\title{
The Influence of Cash Flows on Growth of Deposit Taking SACCOs in Nairobi County
}

\author{
Purity Wairimu Munyiri \& Dr Sussy Wekesa
}

\begin{abstract}
Department of Entrepreneurship, Technology, Leadership and Management, Jomo Kenyatta University of Agriculture \& Technology P.O. BOX 62000-00200 Nairobi, Kenya, Purity W Munyiri P.O. Box 14073- 00100 Nairobi.
\end{abstract}

\begin{abstract}
The cooperative sector plays a crucial role in country's socio-economic development significantly contributing to Nation's Gross Domestic Product. SACCOs play an increasingly important role in Kenya's financial sector, serving a growing number of both urban and rural poor households. The objective of this study was to establish the influence of cash flows on the growth of deposit taking SACCOs in Nairobi County. Management face the challenge to grow profits and such comes with increased risks. The study adopted descriptive research design in which the data was gathered just once over the period 2013 to 2015 to build a strong case on the topic of study. The main characteristic of this method is that the researcher has no control over the variables; he can only report what has happened or what is happening. In this research 41 deposit taking SACCOs in Nairobi County were studied in order to establish the factors that influence their growth. All the deposit taking SACCOs in Nairobi County were covered, no element of chance was left and highest accuracy was obtained. When the universe is a small one, it is no use resorting to a sample survey. The data collection method used is questionnaire however a pilot study was conducted to test its reliability and validity. The data collected was analysed using SPSS to ensure it is accurately evaluated and presented. The regression analysis conducted established that cash-flows had a positive correlation with the dependent variable; thus contributed to the positive growth of the SACCOs. The study found that cashflow to meet loan demand in SACCOs have improved over the years as well as compliance with SASRA ratios. This means that liquidity has improved to cater for the member's loan demands.
\end{abstract}

Keywords: Cash-flow, deposit taking SACCOs, Growth, Loan, Profit

\section{INTRODUCTION}

In Kenya, the history of cooperatives dates back to 1908 and has continued to grow since then. The first co-operative society was established in Kenya in 1908 that is a dairy Co-operative. The Government's first formal involvement in Cooperatives was in 1931when the first Co-operative ordinance was enacted to regulate the operations of co-operatives. Examples of cooperatives then were Kenya Co-operative Creameries (KCC) in 1925, Kenya Planters Co-operative Union (KPCU) in 1923 and Kenya Farmers Association (KFA) in 1923. These organizations were originally registered as companies and only became registered as co-operatives in 1931 when the first Co-operative ordinance was promulgated (Gatuguta et al., 2014). The co-operative sector has been growing since then especially in the rural areas due to agricultural activities whereas in the urban areas they arise due to people working mainly under same employer or industry. The SACCOs in Kenya are confronted by myriad challenges that include poor record keeping, loan backlogs, high illiteracy level among the SACCO members, audit arrears, managerial deficiency, inadequate capital and heavy taxation. A study by WOCCU (2008) revealed that SACCOs are facing severe liquidity problems and majority are unable to meet the demands of their clients for loans and withdrawal of savings. Ondieki et al., (2011) contend that inadequate managerial skills and knowledge have adversely affected SACCOs in Kenya. A deposit taking SACCO offers Front Office Service Activities (FOSA), which are services similar to those offered in the bank. They are regulated by SASRA to ensure the member's interest remain at hand. It is therefore a requirement to submit monthly and quarterly financial reports to SASRA which is used to assess their capital adequacy, liquidity, investment and profit level to evaluate compliance with the set standards. SACCOs in Kenya are licensed annually, thus the submitted reports determine whether a SACCO will be licensed to operate during the following calendar year. 


\section{STATEMENT OF THE PROBLEM}

Liquidity is computed by dividing current assets by current liability. Liquidity represents the capital amount that is available for use as expenditure or in investment. It also shows the ability of a firm to meet their current liabilities as and when they fall due. Excessive amounts of current assets owned by a firm would perhaps increase the chances of internal funding resulting in a relation between leverage and liquidity (Bhunia et al., 2012). Sufficient liquidity has the impact on the financial strength of a firm (Bei et al., 2012). SACCOs in Kenya are faced by such challenges as, poor governance and lack of members' confidence among others (Ademba, 2011); while Ndung'u (2010) adds that the SACCOs are encompassed by mismanagement and poor investment decisions. Among the major problems hindering good financial performance in SACCOs is lack of proper investment decisions, lack of investment opportunities, delayed cash flow from members and dubious investments which have very little or no gain to the members capital due to under regulation (Ahmed, 2004). This study pursued to fill the knowledge gap on the influence of cash-flows on growth of deposit taking SACCOs of Nairobi County with an aim of strategizing on improving their operations for the benefit of the members and the country. Financial institution's role in the economy of any country is very significant, they play intermediation function in that they collect money from those who have excess and lend it to others for their investment and other needs. Excessive amounts of current assets owned by a firm would perhaps increase the chances of internal funding resulting in a relation between leverage and liquidity (Bhunia et al., 2012). Sufficient liquidity has the impact on the financial strength of a firm (Bei et al. 2012). The sustainability of a SACCO depends largely on their ability to collect their loans as efficiently and effectively as possible. Therefore to be financially viable or sustainable, financial institutions must ensure high portfolio quality based on $100 \%$ repayment, or at worst low delinquency, cost effective recovery and efficient lending (Maina et al., 2014).

\section{LITERATURE REVIEW}

The used two theories that are relevant to this study namely Agent Theory and Free cashflow theory. According to Mwende et al., (2015), Ross and Mitnick (1972) came up with agency theory, whereby the principal delegates or hire an agent to perform work. Agency theory suggests that the firm can be viewed as a nexus of contracts between resource holders. The primary agency relationships in business are those between stockholders and managers and between debt holders and stockholders. The SACCOs' staff manages member's funds by disbursing loans and ensuring recovery, however sometimes loans disbursed may not be fully recovered. This may be due to disbursement of loans to non-credit worthy members which influence negative financial performance of the SACCO. Free cash-flow theory implies that free cash flow is cash flow in excess of that required to fund all of a firm's projects that have positive net present values when discounted at the relevant cost of capital. Such free cash flow must be paid out to shareholders if the firm is to be efficient and to maximize value for shareholders.

\subsection{Conceptual Framework}

\begin{tabular}{|l|l|}
\hline Cash-flow & \\
- Member's contribution & Loan demand
\end{tabular}$\quad \begin{aligned} & \text { Growth of Deposit Taking SACCOs } \\
& \text {-Profit } \\
& \text {-Turnover }\end{aligned}$

\section{Independent Variables}

\section{Dependent Variable}

\section{Figure 1}

The core objective of SACCOs is to ensure members empowerment through mobilization of savings and disbursement of credit (Ofei, 2001). Thus SACCOs have been able to recruit members to a point that demand for loans affects the SACCO's cash flow, hence the loan demand is normally in excess of the share deposits (Nyabwanga, 2011). If the members' contribution is continuous and large, the cash flow is sufficient and loan disbursement delays are unheard of. Cash flow on the other hand, if not sufficient, the SACCO may not meet the demand of the members. Once members' needs are not met they withdraw from the SACCO leading to reduced loan portfolio and decreasing income to the SACCO. Cash management is the process of planning and controlling cash flows into and out of the business, cash flows within the business, and cash balances held by a business at a point in time (Pandey, 2004). As Nyabwanga (2011) emphasize that, setting up of cash balance policy ensures prudent cash budgeting and investment of surplus cash. Reduction of the time cash is tied up in the operating cycle improves a business's profitability and market value furthers the significance of efficient cash management practices in improving business performance. Liquidity risk needs to be monitored as part of an integrated institution wide risk management process taking into account market and credit risk to ensure stability and improvement of loan portfolio in the balance sheet. Liquidity risk is a failure of SACCOs to honor 
approved loans due to inadequacy of loanable funds (Fiedler et al., 2002). This in turn affects their income negatively leading to reduced income or losses affecting the SACCOs growth. According to Nyabwanga (2011), working capital management is a very important component of corporate finance because it directly affects the liquidity, profitability and growth of a business and is important to the financial health of businesses of all sizes as the amounts invested in working capital are often high in proportion to the total assets employed. Management of short-term assets is as important as the management of long-term financial assets, since it directly contributes to the maximization of a business's profitability, liquidity and total performance (Nyabwanga, 2011). Consequently, businesses can minimize risk and improve the overall performance by understanding the role and drivers of working capital.

\section{RESEARCH METHODOLOGY}

A research design is a plan, structure and strategy of investigation to obtain answers to research questions and control variance (Ogula, 2005). Therefore research designs are invented to enable answering the research questions as validly, objectively, accurately and as economically as possible. Descriptive research was used in this study as it is concerned with describing the characteristics of a particular individual, or of a group. The research design make enough provision for protection against bias and maximise reliability, with due concern for the economical completion of the research study. Descriptive research includes surveys and factfinding enquiries of different kinds. The major purpose of descriptive research is description of the state of affairs as it exists at present (Kothari, 2009). This method of investigation allowed the researcher to examine issues that relate to growth of deposit taking SACCOs, collect and analyze data in order to describe the phenomenon in its current status. The number of deposit taking SACCOs with head office in Nairobi were 41, thus census was used to study all units of the population because the universe is small. The questionnaires were used to collect data from managers; considering they have access to all the data in the SACCOs. Pilot survey is the replica and rehearsal of the main survey. The researcher measured the reliability and validity of the questionnaire to determine its consistency in testing what they are intended to measure. The pre-test technique was used to estimate the reliability of the instruments.

\section{Research Findings}

The data was then analysed using descriptive and inferential statistical measures as follows:

\subsection{Demographic Characteristics of Respondents}

From the data collected the total actual response percentage was $73.2 \%$ while the remaining $26.8 \%$ had not yet returned their questionnaires due to time factor. The position of the respondents is per the Fig. 2 below.

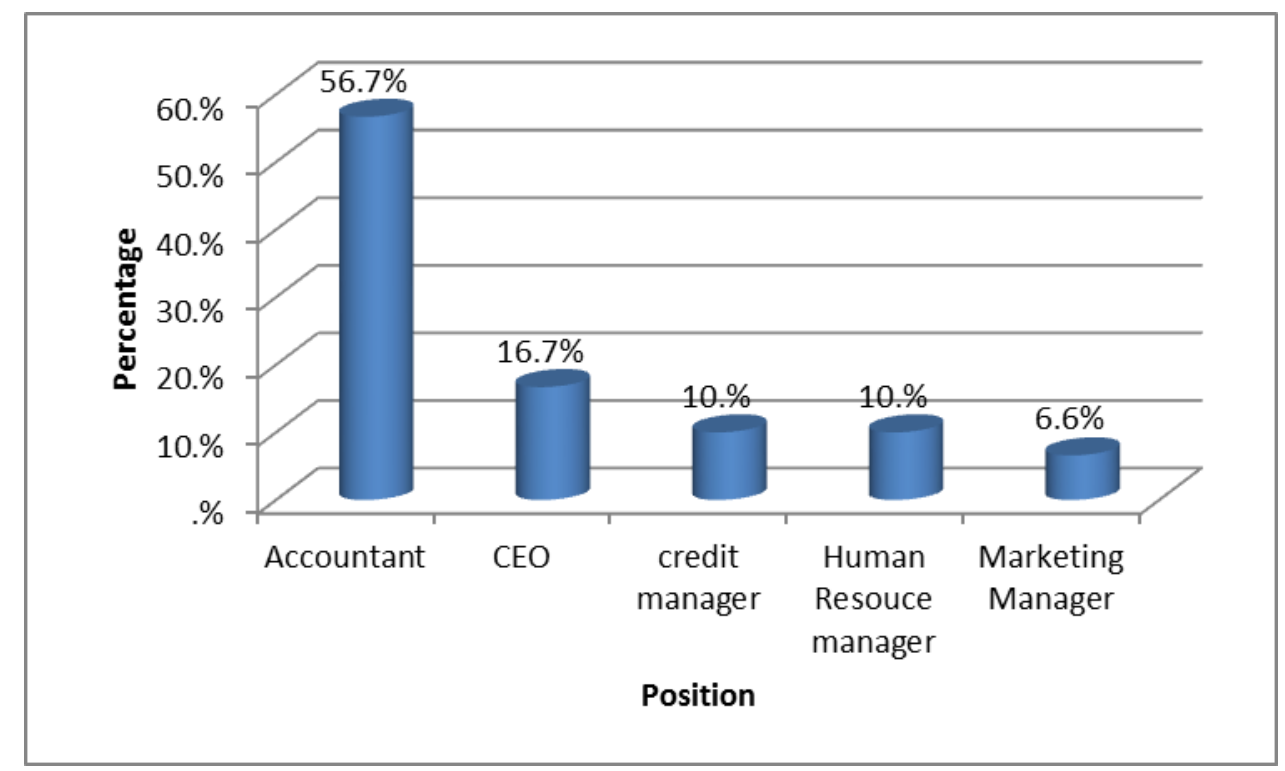

Figure 2: Position of Respondents

The respondents were asked on the number of years they had worked in their respective SACCOs to assess viability of the information given. $63.34 \%$ of the respondents had worked in their SACCOs for a at most 5 years 
while, $20 \%$ of the respondents had worked for 6 to 10 years, $13.33 \%$ of the respondents had worked for 16 to 20 years, while $3.33 \%$ of the respondents had worked for at least 21 years. This strengthened the data collection as the respondents had wide knowledge of the operation of the Sacco on the period under review as $86.6 \%$ had worked in their respective SACCOs for 3years and above.

Table 1: Years worked in the SACCO

\begin{tabular}{llc}
\hline Number of Years Worked & Frequency & Percentage \\
\hline 5 and below & 19 & 63.34 \\
$6-10$ & 6 & 20.00 \\
$11-15$ & 0 & 0 \\
$16-20$ & 4 & 13.33 \\
21 and above & 1 & 3.33 \\
\hline Total & $\mathbf{3 0}$ & $\mathbf{1 0 0}$ \\
\hline
\end{tabular}

The respondents were also asked on where they derive members from and the number of members. This aimed at enabling the researcher to capture the various sectors that form the deposit taking SACCOs in Nairobi County. The deposit taking SACCOs derive members from government, private, Non-governmental organizations and the informal sector, thus data collected was spread across different types of SACCOs. The number of members reflects the SACCOs growth in recruitment in addition to its stability. The highest percentage of SACCOs had members below 20,000 implying that they still have the capacity to grow. The data in frequency and percentage is as presented on Table 2 below.

Table 2: Membership of SACCOs

\begin{tabular}{lcc}
\hline Range of Members & Frequency & Percentage \\
\hline $1-20000$ & 23 & 76.7 \\
$20001-40000$ & 3 & 10 \\
$40001-60000$ & 1 & 3.3 \\
$60001-80000$ & 2 & 6.7 \\
80001 and above & 1 & 3.3 \\
\hline Total & $\mathbf{3 0}$ & $\mathbf{1 0 0}$ \\
\hline
\end{tabular}

\subsection{Descriptive Statistics}

The respondents were asked on the level of cash flow in their SACCO, in order to assess the ability to meet loan demand and compliance with the SASRA ratios for the three years under study. The study sought to understand the compliance of the deposit taking SACCOs in Nairobi County with SASRA ratios. In year 2013 the respondents were neutral that the SACCOs complied with SASRA ratios, however the respondents agree that there was compliance with SASRA ratios in years 2014 and 2015 with a mean of 3.3667 and 3.5333 respectively. The researcher observed that the cash-flows improved over the three year because the compliance with SASRA ratios had improved from a mean of 3.0333 in year 2013 to 3.5333 in year 2015. This study established that SASRA regulations had led to improved management of the deposit taking SACCOs in Nairobi County. The researcher found out that improvement in cash flow levels and compliance with SASRA ratios had led to growth of the SACCOs. The findings are as per the Table 3 below:

Table 3 Influence of Cash-flow on Growth of Deposit taking SACCO

\begin{tabular}{lrr}
\hline Statement & Mean & Std. Deviation \\
\hline SACCO had sufficient cash flow to meet the loan demand in 2013 & 2.8000 & 0.92476 \\
SACCO had sufficient cash flow to meet the loan demand in 2014 & 3.1000 & 0.92289 \\
SACCO had sufficient cash flow to meet the loan demand in 2015 & 3.2000 & 0.99655 \\
SACCO complied with SASRA ratios on liquidity in 2013 & 3.0333 & 0.85029 \\
SACCO complied with SASRA ratios on liquidity in 2014 & 3.3667 & 0.66868
\end{tabular}




\subsection{Regression Analysis}

The regression analysis for cash-flow in relation to the profits of deposit taking SACCOs showed a strong positive relationship between the two variables. The results were computed at $95 \%$ confidence level and are summarized and presented on table 5 below.

Table 4: Cash-flow in relation to the Profits of deposit taking SACCOs in Nairobi County

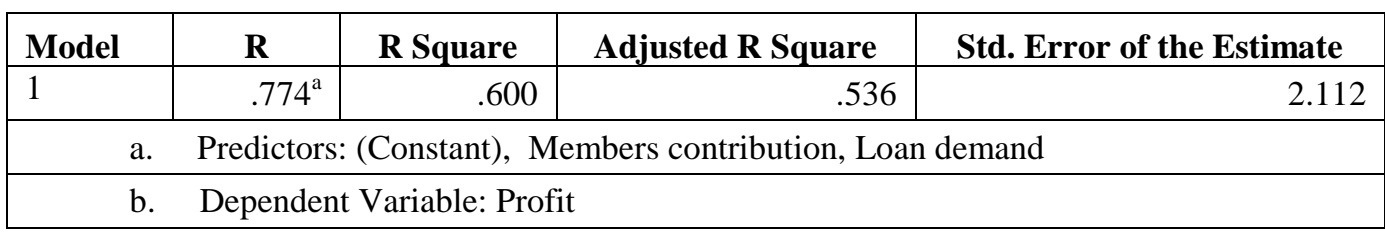

$\mathrm{R}$ square value was found to be 0.6 ; implying $60 \%$ variability in achieving growth in profits in the deposit taking SACCOs in Nairobi County is explained by cash-flows. The other part of variation of $40 \%$ is explained by other factors.

Table 5: Cash-flow in relation to the Turnover of deposit taking SACCOs in Nairobi County

\begin{tabular}{|c|c|c|c|c|}
\hline Model & $\mathbf{R}$ & $\begin{array}{c}\mathbf{R} \\
\text { Square } \\
\end{array}$ & Adjusted R Square & Std. Error of the Estimate \\
\hline 1 & $.480^{\mathrm{a}}$ & .231 & .107 & 2.086 \\
\hline & \multicolumn{4}{|c|}{ Predictors: (Constant), Members contribution, Loan demand } \\
\hline & \multicolumn{4}{|c|}{ Dependent Variable: Turnover } \\
\hline
\end{tabular}

The regression analysis for cash-flow in relation to the turnover showed a moderate relationship between the cash-flow and the turnover of the deposit taking SACCOs in Nairobi County as shown on the table 5 above. The $\mathrm{R}$ square was found to be 0.231 which implies that $23.1 \%$ variability of turnover is attributed to Cash-flows in the deposit taking SACCOs in Nairobi County. The other variation of $76.9 \%$ is explained by other factors.

\subsection{Findings}

\subsubsection{Cash flow and Growth of SACCOs}

The study found that cashflow to meet loan demand in SACCOs have improved over the years as well as compliance with SASRA ratios. This means that liquidity has improved to cater for the member's needs. SACCO's cash flow is attributed by investment income, growth in members and efficient loan recovery measures. With enhanced liquidity, the compliance with SASRA regulations was improved. This also contributes to stability of the SACCOs due to the strong membership. SACCOs pay returns to the shareholders and stockholders in terms of dividends and bonuses. In SACCOs free cash flow enhances the ability to meet the loan demand by its borrowers. This leads to growth on the loan portfolio which may influence growth of the SACCO's depending on loan recovery. According to Kinyanjui (2014), capital expenditure is strongly and positively associated to the level of free cash flow thus the more free cash flows a firm has the more investments the firm can engage in.

\section{CONCLUSION}

The researcher concluded that retrenchment, employer delays in submission of deductions are the major causes of crawling growth of income in SACCOs as they contributed to loan default. SACCOs need to be more innovative in debt collection measures, maintaining sufficient cash flow and continuous training on investment to both the staff and BODs. Management of loan portfolio has proved to be the cornerstone of financial organisations and SACCOs being one they cannot survive without securing loans disbursed in addition to stringent debt collection measures. The researcher recommends that the SACCOs should manage their loan portfolio to ensure they are performing in order to grow. The employers should make timely remittance to the SACCOs because it affects the loan performance and cash-flow as well. 


\section{RECOMMENDATION}

The SACCOs should capitalize on member retention as it determines it's stability by constantly education them especially on personal financing as it would reduce the rate of defaulted loans. SACCOs can also focus on the data that they collect from the members during recruitment as this enhances follow-up even in cases of loan default. All SACCOs should strive towards over $95 \%$ performing loans for their stability and growth. SACCOs need to be more innovative in debt collection measures, maintaining sufficient cash flow and continuous training on investment to both the staff and BODs.

\section{Acknowledgements}

I thank The Almighty God for His favour and protection towards me. I am grateful to my supervisor Dr. Suzzy Wekesa for her professional guidance and advice throughout the research period. I thank my colleagues, friends, family members and classmates especially Esther and Florence for their solid encouragement during proposal development and final completion of this project. I acknowledge my fiancé Eustus Kariuki for the support and reassurance that I would make it.

\section{REFERENCES}

Gatuguta, A.M., Kimotho, P. \& Kiptoo, S. (2014). History and organization of cooperative development and marketing sub sector in kenya, Republic of Kenya.

Ondieki, A., Okioga, C. , Okwena, D. K., \& Onsase, A. (2011). Assessment of the Effect of External Financing on Financial Performance of Savings and Credit Cooperatives in Kisii Central District, Kenya.

Bhunia, A. (2012). Leverage Impact on Firms Investment Decision: A Case Study of Indian Pharmaceutical Companies, International Journal of Contemporary Business Studies, 3 (1), 35-45.

Bei, Z., \& Wijewardana, W. ( 2012 ). Financial leverage, firm growth and financial strength in the listed companies in Sri Lanka', Procedia Social and Behavioral Sciences 40(3), 709-715.

Ademba, C. (2011). Benefits of Regulated SACCO subsector: SACCO Star.

Ndung'u, G. (2010). Orderly movement. Business Post.

Maina, E. \& Kalui, F. (2014). Assessing Institutional Factors Contributing to Loan Defaulting In Microfinance Institutions in Kenya. IOSR Journal of Humanities and Social Sciences, 19(5), 80-84.

Mwende, M., Bichanga, J., \& Mosoti J. (2015). Investigation on Factors Facilitating Accessibility of Banking Services through Agency Banking in Kenya: (A Case of Equity Bank) in Kitui Central District, Kitui County, Kenya., International Journal of Scientific and Research Publications, 5( 8), 1-8.

Ofei, K.A. (2001). Retooling credit unions: The case of credit union association of Ghana. IFLIP Research Paper. Research Paper, International Labour Organization, University of Ghana, Legon.

Nyabwanga, R., Ojera. P., Alphonce. J., \& Otieno. S. (2011). Effect of working capital management practices on financial performance: A study of small scale enterprises in Kisii South District, Kenya. Kenya, African Journal of Business management, 6(18), 58075817.

Ogula, P. A. (2005). Research Methods. Nairobi: CUEA Publications.

Kothari, C.R. (2009). Research Methodology: Methods and Techniques. $2^{\text {nd }}$ ed; New Delhi: New Age International Publishers.

Kinyanjui, M. (2014). The relationship between free cash flows and investments of firms quoted at the Nairobi securities exchange. 